Article

\title{
Assessing and Improving the Eco-Efficiency of Manufacturing: Learning and Challenges from a Polish Case Study
}

\author{
Magdalena Rybaczewska-Błażejowska * and Aneta Masternak-Janus
}

check for updates

Citation: Rybaczewska-Błażejowska, M.; Masternak-Janus, A. Assessing and Improving the Eco-Efficiency of Manufacturing: Learning and Challenges from a Polish Case Study. Energies 2021, 14, 8125. https:// doi.org/10.3390/en14238125

Academic Editor: Luigi Aldieri

Received: 29 October 2021

Accepted: 16 November 2021

Published: 3 December 2021

Publisher's Note: MDPI stays neutral with regard to jurisdictional claims in published maps and institutional affiliations.

Copyright: (c) 2021 by the authors. Licensee MDPI, Basel, Switzerland. This article is an open access article distributed under the terms and conditions of the Creative Commons Attribution (CC BY) license (https:// creativecommons.org/licenses/by/ $4.0 /)$.
Department of Production Engineering, Kielce University of Technology, Tysiąclecia Państwa Polskiego 7, 25-314 Kielce, Poland; amasternak@tu.kielce.pl

* Correspondence: m.blazejowska@tu.kielce.pl

\begin{abstract}
Manufacturing offers substantial opportunities for economic growth after COVID-19, as long as it delivers competitively priced goods while simultaneously reducing pressure on the environment. In this study, we present the methodological feasibility of the joint application of life cycle assessment (LCA) and data envelopment analysis (DEA) for assessing eco-efficiency at the sector level. We employ this methodology to assess the environmental profiles of manufacturing in Poland in relation to their gross value added, and subsequently calculate the improvement targets for the eco-inefficient manufacturing industries. The study reveals that only the chemical industry is relatively eco-efficient, whereas the remaining industries have considerable room for improvement due to their very low eco-efficiency, and thus should follow the best practices established by the chemical industry. Although there are always individual paths for manufacturing industries to achieve the decoupling of economic growth from environmental pressure, activities such as the transformation of manufacturing methods to be less energy and material intensive and/or to be low-emission, the reincorporation of waste into the manufacturing processes, and the implementation of environmental management systems should become common targets of manufacturing in Poland.
\end{abstract}

Keywords: data envelopment analysis; life cycle assessment; processing industry; circular economy; Poland

\section{Introduction}

Manufacturing is responsible for a considerable amount of environmental impacts. At the same time, however, it provides several benefits in the form of valuable products to society, which cannot be neglected. Nevertheless, meeting the needs and aspirations of the present time should take place without jeopardizing the needs of future generations. Having accepted this fact, it becomes important to take manufacturing activities to a new level that will integrate environmental concerns with products and services. One solution for various environmental problems is orienting towards so-called sustainable manufacturing by implementing solutions focused on eco-efficiency. Promoting eco-efficiency is also one of the major objectives of the circular economy.

Although many definitions of eco-efficiency circulate in the scientific realm, the one introduced by the World Business Council for Sustainable Development (WBCSD) is the most adequate for the specificity of manufacturing. Following the WBCSD, eco-efficiency is achieved by the delivery of competitively priced goods that satisfy human needs while progressively reducing ecological impacts and resource intensity throughout the life cycle [1]. Consequently, the decoupling of economic growth and environmental pressure should be at the heart of all eco-efficient undertakings in manufacturing.

Making the concept of eco-efficiency operational for enterprises requires criteria of environmental performance to track trends over time. Many of the criteria, including the consumption of materials, energy intensity, pollution dispersion, the use of renewable resources, and the extension of product durability, are strongly related to manufacturing [2]. The concept of eco-efficiency, in this sense, is connected to many concurrent concepts 
of sustainable management, including cleaner production, industrial ecology, life cycle thinking, corporate social responsibility, and, finally, circular economy.

The approach to assessing eco-efficiency is regulated by the ISO 14045 standard (environmental management-eco-efficiency assessment of product systems-principles, requirements, and guidelines) [3]. Under this standard, eco-efficiency is a relative measure of sustainability that addresses the relationship between environmental performance and product system value. The eco-efficiency assessment comprises the following five phases: goal and scope definition, environmental assessment, product system value assessment, quantification of eco-efficiency, and interpretation. Considering the nature of the current research, the product system refers to individual manufacturing industries.

To deal with multiple aspects of eco-efficiency, a multi-criteria decision making (MCDM) approach is usually employed. However, considering current legal, societal, and economic macro trends, the assessment of eco-efficiency requires the analysis of environmental performance from a life cycle perspective. In addition to that the fact that data envelopment analysis (DEA) constitutes the preferred approach to quantifying eco-efficiency, the joint application of life cycle assessment (LCA) and DEA allows the measurement of progress in eco-efficiency. It integrates both the environmental impacts derived from the LCA analysis and the economic results in a single eco-efficiency score through a system of weight estimation based on DEA [4]. Furthermore, it provides detailed benchmark data to reduce potential environmental impacts [5].

Although previous research has confirmed the high applicability of the LCA+DEA methodology to eco-efficiency measurement in various case studies, this research has provided little insight into eco-efficiency measurement at the sector level. To the best knowledge of the authors, with regards to the eco-efficiency of manufacturing, there is little research based on the LCA+DEA methodology: that of some U.S. manufacturing sectors [6], U.S. food manufacturing sectors [7], some EU manufacturing sectors [8] and China's economic sectors [9]. However, they all employ an input-output life cycle assessment (EIO-LCA).

This study aims to address the knowledge gap in the current literature in two different ways. First, from a methodological viewpoint, it shows the applicability of the LCA+DEA approach for measuring the eco-efficiency performance at the sector level. This is the first attempt of this type for manufacturing in the European Union. Second, from a practical viewpoint, the study contributes to the limited research on the eco-efficiency of manufacturing in Poland. Although eco-efficiency of manufacturing is a research topic with increasing interest, so far only selected aspects of eco-efficiency of the manufacturing processes have been studied, and these have been done using other indicators and methodologies. For example, Masternak-Janus [10] applied the DEA method to convert different environmental impacts created by Polish industries into a single eco-efficiency scores.

We argue that this information, through the development of more effective environmental regulations and better management plans, supports the embedding of sustainability in manufacturing and accelerates the transition towards a circular economy.

The paper is organized in the following way. After the introduction, Section 2 outlines the materials and methods used for the present research, with particular focus on the approach applied to the eco-efficiency measurement using the three-step LCA+DEA methodology. Section 3 presents the results of the eco-efficiency calculation for manufacturing in Poland. Subsequently, the achieved results and their limitations are discussed in Section 4, followed by the conclusions in Section 5 .

\section{Materials and Methods}

The three-step LCA+DEA methodology was applied for the eco-efficiency assessment of manufacturing in Poland. The main benefit of combining LCA+DEA is the enrichment of the eco-efficiency quantification and interpretation with the environmental performance indicators analyzed over the entire life cycle $[4,11,12]$. The three-step LCA+DEA methodology consists of the following steps (Figure 1): 
I. Development of the life cycle inventory (LCI) for each manufacturing industry individually. This involves the collection and quantification of relevant environmental data, including indicators of natural resources and materials consumption, and environmental pressure indicators for the analyzed industry;

II. Performance of the life cycle impact assessment (LCIA) for every manufacturing industry on the basis of the LCI results obtained in the first step;

III. Calculation of the eco-efficiency performance for each manufacturing industry with use of the DEA method, using the results of the LCIA phase as input values and economic indicators as output values. This stage includes the process of environmental benchmarking for improvements in eco-efficiency.
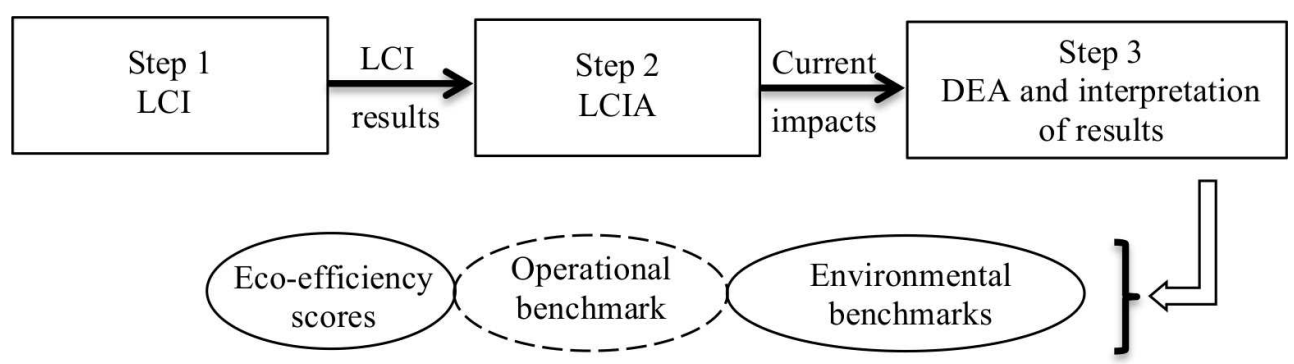

Figure 1. Schematic presentation of the three-step LCA+DEA methodology [12,13].

A characteristic feature of the three-step LCA+DEA methodology is that the output parameters of the previous step become the input parameters of the next step. There are, however, many arguments for such methodological proceedings. The first step forms the basis for the analysis by providing the appropriate inputs and outputs. The second step constitutes an environmental life cycle assessment of each studied manufacturing industry. And finally, the third step allows for obtaining environmental benchmarks, without excluding the possibility of obtaining operational benchmarks simultaneously.

Life cycle assessment (LCA) is regulated by the ISO 14040 (environmental managementlife cycle assessment - principles and framework) and ISO 14044 (environmental managementlife cycle assessment-requirements and guidelines) standards [14,15]. LCA provides a compilation and evaluation of the inputs, outputs, and potential environmental impacts related to a given product system throughout its life cycle or specific parts of this life cycle [14]. The LCA methodology is structured along the following four-phase framework: goal and scope definition, inventory analysis, impact assessment, and interpretation. Considering the nature of the research, it follows an attributional approach.

The goal of this LCA study is to identify hot spots for the improvement of environmental performance of manufacturing in Poland. For this purpose, process-based cradle-to-gate modeling is applied. Due to the fact that the current LCA is performed at the sector level, the monetary-based functional unit of EUR 1000 referring to the value of sold production of industrial products was selected.

The scope of the analysis covers manufacturing in Poland. Following the statistical classification of economic activities in the European Community, it involves the complete manufacturing processes of the physical and/or chemical transformation of raw materials or semi-finished products of other manufacturing activities into new products [16]. The output of a manufacturing process (new product) is either ready for consumption or is used as an input for further manufacturing. As defined, manufacturing in Poland covers a set of 11 industries, including the food industry (manufacture of food, beverages, and tobacco products), textile and clothing industry (manufacture of textiles, wearing apparel, leather, and related products), wood industry, paper industry, chemical industry (manufacture of chemicals and chemical products, coke and refined petroleum products, pharmaceutical products, rubber, and plastic products), building materials industry, metal industry, electrotechnical and electronic industry (manufacture of computers, electronic and optical products, and electrical devices), machine industry, automotive industry (man- 
ufacture of motor vehicles, trailers, semi-trailers, and other transport equipment) and furniture industry.

\subsection{Life Cycle Inventory (LCI)}

Life cycle inventory (LCI) constitutes the second phase of LCA. It refers to the collection and quantification of environmental inputs and outputs for the product system $[14,15]$. The term "environmental inputs and outputs" refers to elementary flows associated with the analyzed product system in the form of materials, energy, water, and releases, including emissions to air and discharges to water and soil, as well as waste.

Regarding the LCI of manufacturing in Poland, a set of environmental inputs encompasses the following indicators of natural resources and materials consumption:

1. Consumption of electricity [in GWh];

2. Consumption of hard coal [in thousands Mg];

3. Consumption of natural gas (including high-methane natural gas and nitrified natural gas) [in $\mathrm{hm}^{3}$;

4. Consumption of coniferous sawnwood [in $\mathrm{dam}^{3}$;

5. Consumption of particle boards [in $\mathrm{dam}^{3}$ ];

6. Consumption of paper and paperboard [in thousands $\mathrm{Mg}$;

7. Consumption of plastics [in thousands $\mathrm{Mg}$ ];

8. Consumption of cement [in thousands Mg];

9. Consumption of steel (including: hot rolled products, cold rolled steel sheets, zinc coated steel sheets, and steel tubes) [in thousands Mg];

10. Consumption of water [in $\left.\mathrm{hm}^{3}\right]$.

A set of environmental outputs encompasses the following environmental pressure indicators:

1. Emissions to air (including carbon monoxide, carbon dioxide, sulphur dioxide, and particulates < $2.5 \mu \mathrm{m}$ ) [in thousands $\mathrm{Mg}$ ];

2. Production of wastewater $\left[\mathrm{in} \mathrm{hm}^{3}\right]$;

3. Production of waste [in thousands $\mathrm{Mg}$ ].

The choice of environmental inputs and outputs for the LCIA calculation of manufacturing in Poland was dictated by the availability of data from the Central Statistical Office of Poland. It ought to be emphasized, though, that in order to present the environmental state of manufacturing as comprehensively and objectively as possible, all publicly available environmental data were applied to this research. Missing data regarding upstream processes were retrieved from the Ecoinvent database.

\subsection{Life Cycle Impact Assessment (LCIA)}

Life cycle impact assessment (LCIA) constitutes the successive phase of LCA. It involves a complex sequence of steps aimed at understanding and evaluating the magnitude and significance of environmental inputs and outputs, identified in the LCI phase [14,15]. Due to the character of the current study, besides the mandatory steps of classification and characterization, the optional step of normalization was performed.

The International Reference Life Cycle Data System (ILCD) midpoint-oriented method, released by the European Commission-Joint Research Centre-Institute for Environment and Sustainability, was applied to present the environmental profiles of manufacturing in Poland. Consequently, LCI results were assigned to the following harmonized set of midpoint impact categories: climate change ( $\left.\mathrm{kg} \mathrm{CO}_{2} \mathrm{eq}\right)$, ozone depletion ( $\left.\mathrm{kg} \mathrm{CFC}-11 \mathrm{eq}\right)$, human toxicity, non-cancer effects (CTUh), cancer effects (CTUh), particulate matter formation (kg PM2.5 eq), ionizing radiation $\mathrm{HH}(\mathrm{kBq} \mathrm{U} 235 \mathrm{eq})$, ionizing radiation $\mathrm{E}$ (interim) CTUe, photochemical ozone formation ( $\mathrm{kg}$ NMVOC eq), acidification (molc $\mathrm{H}+\mathrm{eq}$ ), terrestrial eutrophication (molc $\mathrm{N} \mathrm{eq}$ ), freshwater eutrophication ( $\mathrm{kg} \mathrm{P} \mathrm{eq),} \mathrm{marine} \mathrm{eutrophication}$ ( $\mathrm{kg} \mathrm{N} \mathrm{eq}$ ), freshwater ecotoxicity (CTUe), land use ( $\mathrm{kg} \mathrm{C} \mathrm{deficit),} \mathrm{water} \mathrm{resource} \mathrm{depletion}$ $\left(\mathrm{m}^{3}\right.$ water eq), and mineral, fossil, and renewable resource depletion ( $\mathrm{kg} \mathrm{Sb}$ eq) $[17,18]$. The 
selection of the ILCD method was dictated by the fact that it provides a common basis for a consistent, holistic, and quality assured approach to impact assessment.

Due to its complexity, the LCIA research was facilitated with life cycle software SimaPro 9.1 (developed by PRé Sustainability PRé Consultants; Amersfoort, The Netherlands).

\subsection{Data Envelopment Analysis (DEA)}

Data envelopment analysis (DEA) is a non-parametric technique based on linear programming that calculates the relative efficiency of a set of homogeneous units, usually called decision-making units (DMUs). The units convert multiple inputs into multiple outputs [19]. Thus, the DEA method considers the input and output resources of the tested DMUs and calculates their individual performance scores $(\theta)$, which are in the range $0-1$. In other words, this method determines the ability of the DMUs to get the minimum possible number of inputs for a given level of outputs (in input-oriented DEA models) or the maximum possible number of outputs for a given level of inputs (in output-oriented DEA models) [20]. Effective units can be used as benchmarks for the ineffective ones, giving them suggestions for improvement [21].

Out of the large variety of models of DEA presented in the literature, the BCC (Banker/Charnes/Cooper) model was selected for research into the eco-efficiency of manufacturing in Poland [22]. It assumes variable returns to scale (VRS), which means that an increase or decrease in inputs or outputs does not bring about a respective proportional change in the outputs or inputs [23]. This model estimates pure technical efficiency and thus ignores the scale size. Therefore, its use is recommended when the DMUs are different firms or organizations that may not operate optimally due to actual competition and financial restrictions [24]. Moreover, the lack of homogeneity of these units is not a problem for the BCC model [25].

Since minimization of environmental impacts at a given level of economic results should be a priority in enterprises, the input-oriented BCC model was used in this study. Its dual form is as follows:

$$
\begin{gathered}
\min \theta_{\mathrm{o}} \\
\sum_{j=1}^{\mathrm{J}} \mathrm{x}_{\mathrm{nj}} \lambda_{\mathrm{oj}} \leq \mathrm{x}_{\mathrm{no}} o_{\mathrm{o}} \\
\sum_{\mathrm{j}=1}^{\mathrm{J}} \mathrm{y}_{\mathrm{rj}} \lambda_{\mathrm{oj}} \geq \mathrm{y}_{\mathrm{ro}} \\
\sum_{\mathrm{j}=1}^{\mathrm{J}} \lambda_{\mathrm{oj}}=1 \\
\lambda_{\mathrm{oj}} \geq 0
\end{gathered}
$$

where:

$\theta_{\mathrm{O}}$ - eco-efficiency score of the tested DMU;

$x_{n j}$-amount of the n-th input for the $j$-th DMU;

$\mathrm{x}_{\mathrm{no}}$-amount of the $\mathrm{n}$-th input for the tested DMU;

$\mathrm{y}_{\mathrm{rj}}$ - amount of the r-th output for the j-th DMU;

$\mathrm{y}_{\mathrm{ro}}$ - amount of the $\mathrm{r}$-th output for the tested DMU;

$\lambda_{\mathrm{oj}}$-weight coefficients;

$\mathrm{j}=1, \ldots, \mathrm{J} ; \mathrm{r}=1, \ldots, \mathrm{R} ; \mathrm{n}=1, \ldots, \mathrm{N}$.

\subsection{Variable Selection Methodology}

Maintaining the high discriminatory power of the DEA model requires reducing the long list of variables, so that the following condition is met [26]:

$$
\mathrm{n} \geq \max \{\mathrm{m} * \mathrm{~s}, 3(\mathrm{~m}+\mathrm{s})\}
$$


where:

$\mathrm{n}$-number of DMUs;

$\mathrm{m}$-number of inputs;

s-number of outputs.

Various methodologies are proposed to select the input and output variables for the DEA method. On the one hand, statistical and econometric methods are used, e.g., correlation analysis and Hellwig's method [27,28]. They recommend the removal of inputs that are closely correlated and, therefore, do not provide any relevant information in the model [29]. On the other hand, deterministic methods are applied that eliminate the variables by comparing the efficiency of the extended and reduced models. Thus, the selection process is based on removing inputs whose exclusion will not significantly affect the value of the efficiency score [30]. This study focuses on the second approach, using a backward elimination procedure developed by Jitthavech [31]. It consists of the following steps:

1. Determination of input and output variables that must definitely be included in the BCC model and, therefore, are to be grouped into a Set S1;

2. Determination of the variables that are candidates for the BCC model and, therefore, are to be grouped into a Set S2;

3. Calculating the eco-efficiency for each tested industry using the full BCC model containing candidate variables. This step includes classifying the DMUs as ecoefficient and eco-inefficient;

4. Calculating the eco-efficiency for each tested industry using the reduced BCC model that includes only the mandatory variables. Subsequently, DMUs are classified as eco-efficient and eco-inefficient;

5. Performing the statistical tests to evaluate candidate variables, for example, the McNemar test, which tests the null hypothesis that the number of efficient DMUs in the reduced model is the same as in the full model.

\section{Results}

\subsection{Inventory Data}

A data inventory for manufacturing in Poland was carried out based on the available information published by the Central Statistical Office in Poland [32]. The Table A1 in Appendix A assembles the values of the indicators for the consumption of natural resources and materials, as well as the values of environmental pressure indicators. Moreover, economic indicators such as sold production and gross value added are included.

The consumption of primary and final energy in the analyzed industries shows considerable diversification. The largest recipient of energy is the chemical industry, whose share of the total consumption in 2019 was 29\% for electricity, 59\% for natural gas, and as much as $77 \%$ for hard coal. The most energy-intensive industries also include the metal industry, the food industry, and the building materials industry. Together, they account for over $60 \%$ of all delivered energy use.

The structure of material consumption in industries is definitely related to the type of products being manufactured. Thus, the main recipients of coniferous sawnwood and particle boards are industries focused on the manufacture of wood, cork, and wicker goods, i.e., the wood industry and the furniture industry. In 2019, their consumption accounted for about $96 \%$ of the total consumption of these materials in manufacturing in Poland. The largest use of paper and paperboard is observed in the paper industry, which processes them further. Consequently, it accounts for almost $88 \%$ of the total consumption. Plastics are mainly used by the chemical industry for the manufacture of rubber and plastic products ( $84 \%$ share in total consumption). Finally, the main recipient of steel (metallurgical) products is the metal industry, which deals with the manufacture of, among other things, metal constructions, tanks, cisterns, and metal containers. Its share in the consumption of steel products amounted to almost $60 \%$. 
An indispensable factor in industrial production is water, the largest quantity of which is used in the chemical industry. In 2019, chemical industry enterprises consumed $304.5 \mathrm{hm}^{3}$ of water, which accounted for more than half of the total water consumption in manufacturing in Poland. The amount of water used translates directly into the amount of wastewater drained into waters, the ground, or municipal sewerage networks. Thus, the chemical industry also has the largest share in wastewater emissions. In 2019, it was responsible for over $44 \%$ of industrial wastewater in Poland.

A significant problem for manufacturing in Poland is the amount of particulates and pollutant gases that are emitted, mainly carbon dioxide. In 2019, the overall emissions remained at the level of 60,085.8 thousand $\mathrm{Mg}$. The main source of carbon dioxide emissions is the chemical industry, which derives from the use of fossil fuels as raw materials in production processes. Moreover, manufacturing in Poland is responsible for significant amounts of industrial waste $(27,016.6$ thousand $\mathrm{Mg})$, but the vast majority of waste undergoes recovery and disposal processes. The metal industry has the largest share in the formation of waste, generating over $36 \%$ of industrial waste.

Gross value added in manufacturing in Poland is mainly created by the chemical industry, the food industry, the metal industry, and the automotive industry. The industry with the highest added value is the chemical industry, which in 2019 reached the level of EUR 288,320 million. It should be added that these four leading industries also generate a high value of sold production.

\subsection{Environmental Profiles}

Based on the LCI results, the environmental profiles of manufacturing in Poland were calculated using the ILCD method and the functional unit of EUR 1000. To present the magnitude and significance of the environmental impacts of manufacturing as comprehensively as possible, in addition to the mandatory steps of LCIA, the optional step of normalization was performed. The impact categories of human toxicity, non-cancer effects, and cancer effects were aggregated into human toxicity. Positive values indicate burdens, while negative values indicate savings.

The characterization results revealed that, regardless of the impact category, the metal industry, followed by the machine industry, automotive industry, and furniture industry, have the most detrimental impacts upon the environment (Figure 2 and Table A2 of Appendix B). At the other end of the spectrum is the food industry, followed by the textile and clothing industry, which have the least adverse impacts on the environment. The remaining types of industries have different levels of negative impacts on the environment, depending on the impact category. Thus, the building materials industry has the greatest negative impact on climate change (2166.82 $\mathrm{kg} \mathrm{CO}_{2}$ eq); the chemical industry on water resource depletion $\left(18.02 \mathrm{~m}^{3}\right.$ water eq); the electrotechnical and electronic industry impacts all impact categories with the same intensity; the paper industry on climate change (1779.45 $\mathrm{kg} \mathrm{CO}_{2} \mathrm{eq}$ ) and acidification (8.06 molc $\left.\mathrm{H}+\mathrm{eq}\right)$; and, finally, the wood industry on acidification (4.27 molc $\mathrm{H}+\mathrm{eq})$, freshwater eutrophication $(0.46 \mathrm{~kg} \mathrm{P}$ eq), land use (1010.81 kg C deficit), and water resources depletion (11.23 $\mathrm{m}^{3}$ water eq). 

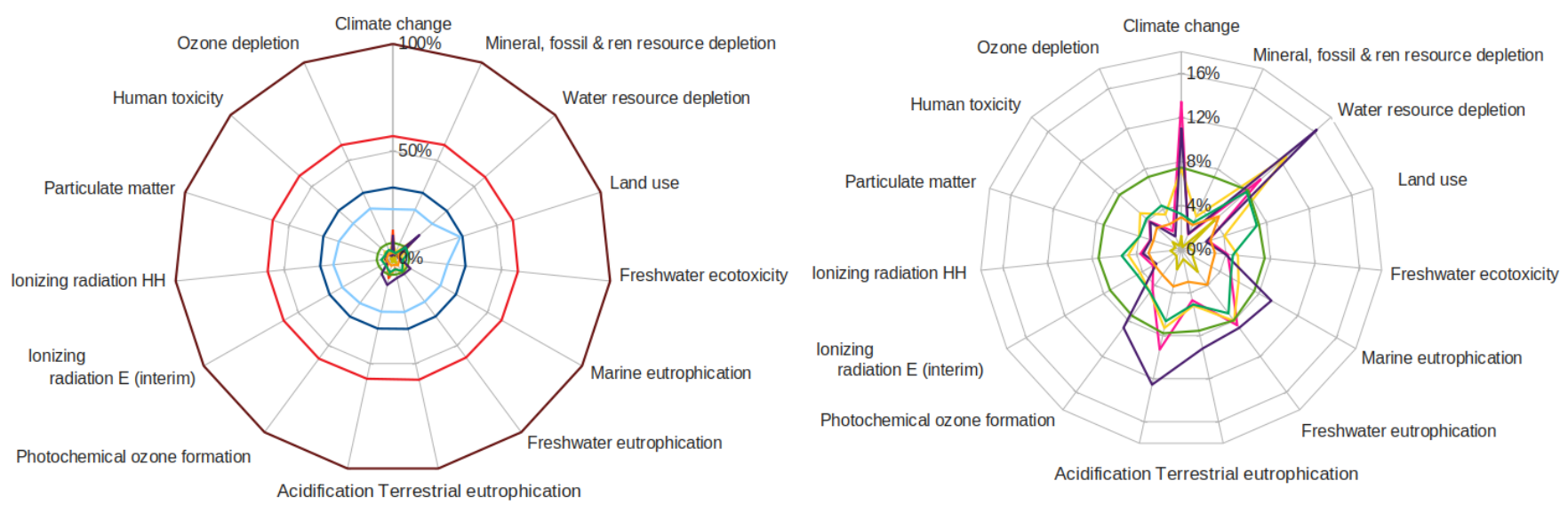

- Automotive industry - Building materials industry - Chemical industry - Electrotechnical and electronic industry - Food industry - Furniture industry
- Machine industry $\quad$ - Metal industry $\quad$ - Paper industry $\quad$ - Textile and clothing industry $\quad$ - Wood industry

Figure 2. Environmental profiles of manufacturing in Poland.

The contribution analysis demonstrated that the consumption of steel products (hot rolled products, cold rolled steel sheets, zinc coated steel sheets, and steel tubes) and the consumption of energy by manufacturing in Poland have the highest negative impacts on the environment (Figure 3 ). The remaining products and processes are very much industryrelated and thus, in the case of the food industry, waste water production additionally plays a significant role in terms of environmental impacts; in the furniture industry, it is the consumption of particle boards; in the textile and clothing industry, the consumption of plastics; in the paper industry, the consumption of paper related products; and finally, in the wood industry, the consumption of particle boards and coniferous sawnwood. Across all the impact categories investigated, environmental savings were only observed in the category of climate change with respect to the wood industry $\left(-210.9 \mathrm{~kg} \mathrm{CO}_{2}\right.$ eq) and water resource depletion with respect to the food industry $\left(-0.21 \mathrm{~m}^{3}\right.$ water eq), the paper industry $\left(-1.18 \mathrm{~m}^{3}\right.$ water eq), and the wood industry $\left(-0.03 \mathrm{~m}^{3}\right.$ water eq).
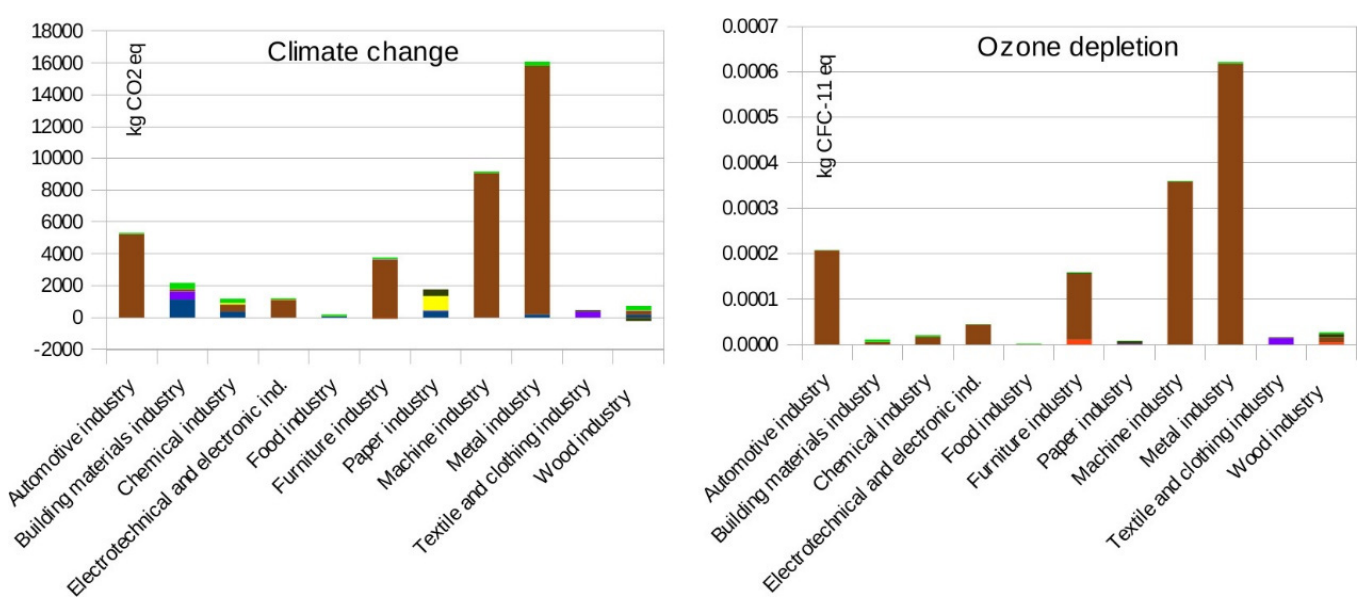

Figure 3. Cont. 

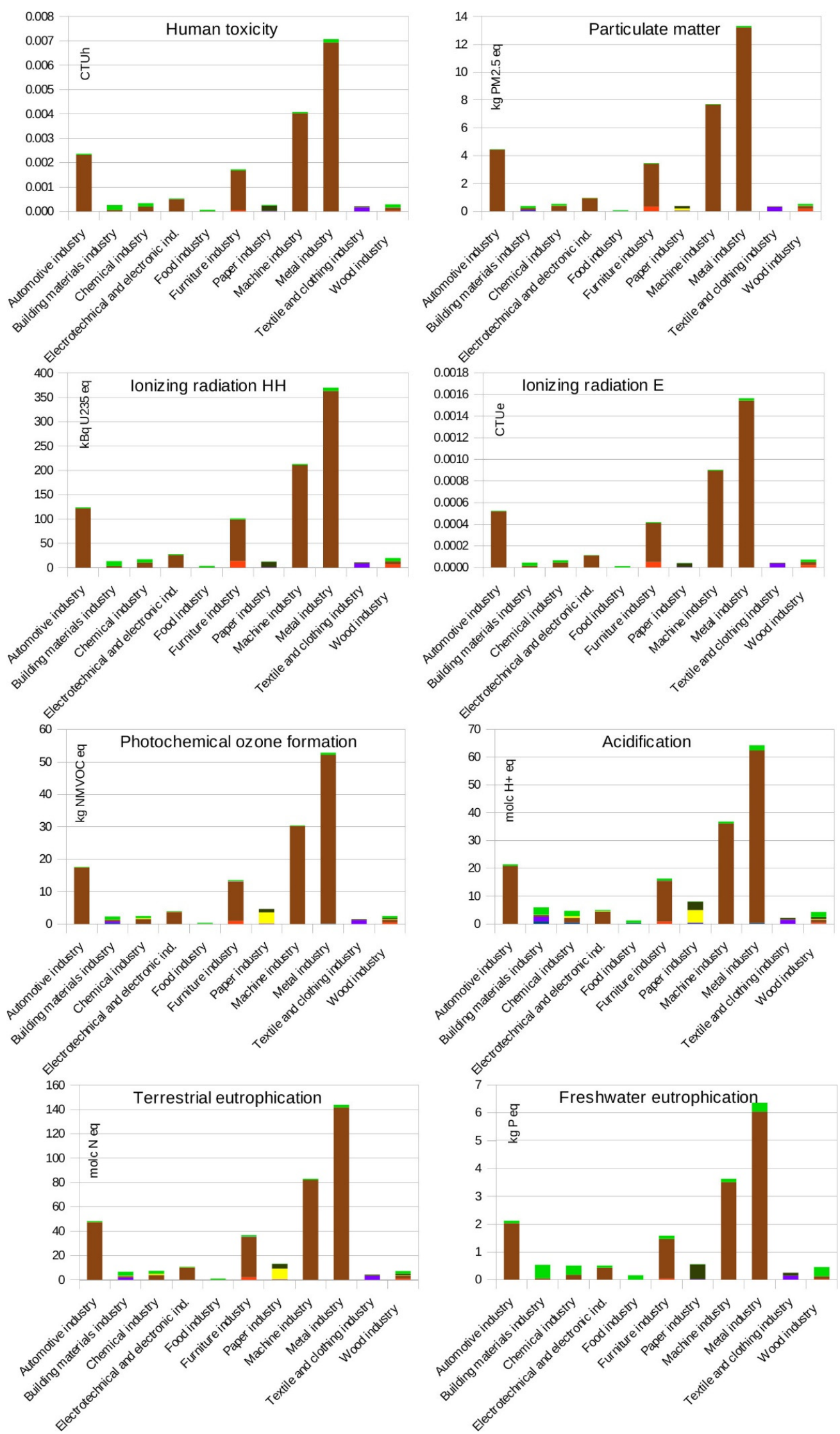

Figure 3. Cont. 


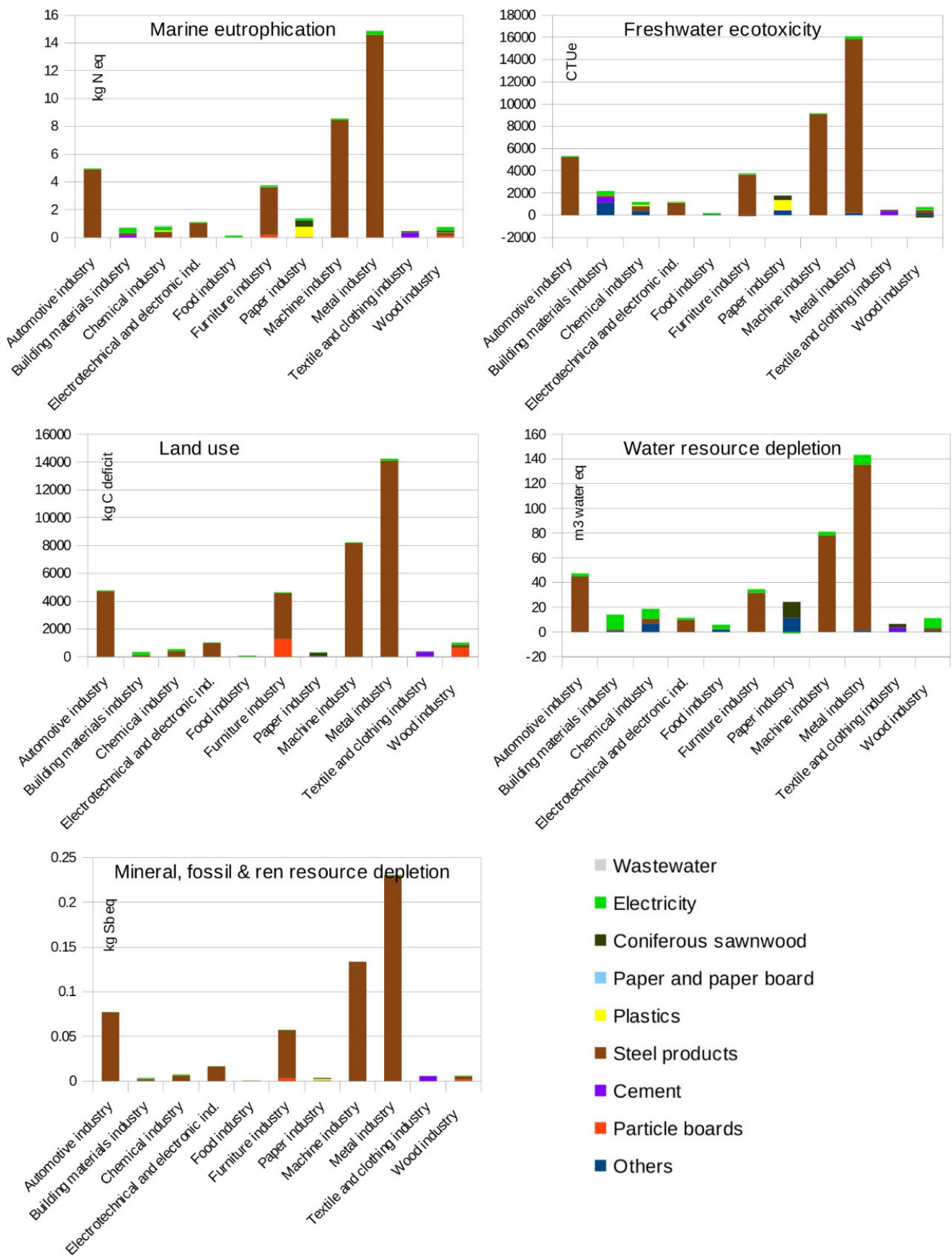

Figure 3. Contribution analysis (with a breakdown into impact categories) of manufacturing in Poland.

The normalization results showed that human toxicity (cancer effects and non-cancer effects) (231.23), followed by freshwater ecotoxicity (39.41) and freshwater eutrophication (11.27), are the focal concerns of manufacturing in Poland (Table A3 of Appendix C). At the other extreme is ionizing radiation $\mathrm{E}$, followed by ozone depletion, land use, and ionizing radiation $\mathrm{HH}$, where the cumulative normalized impact on the environment is below 1 . Additionally, the normalization confirmed that the metal industry has the most adverse impact on the environment in all crucial impact categories, and thus, for instance, in the case of human toxicity, it is responsible for $42.21 \%$ of all negative impacts of manufacturing in Poland. 


\subsection{DEA Performance}

The normalized environmental impact categories and gross value added (GVA) were the foundation for the calculating the eco-efficiency scores for manufacturing in Poland, done with the use of the input-oriented BCC model. First, two sets of input variables were specified: S1 for the variables that are mandatory and S2 for the variables that are candidates in the BCC model. The set of mandatory variables can be represented by significant problem areas, i.e., human toxicity (cancer effects and non-cancer effects) ( $\left.\mathrm{x}_{1}\right)$ and freshwater ecotoxicity $\left(\mathrm{x}_{2}\right)$. Consequently, the remaining variables climate change $\left(\mathrm{x}_{3}\right)$, ozone depletion $\left(\mathrm{x}_{4}\right)$, particulate matter $\left(\mathrm{x}_{5}\right)$, ionizing radiation $\mathrm{HH}\left(\mathrm{x}_{6}\right)$, ionizing radiation interim $\left(\mathrm{x}_{7}\right)$, photochemical ozone formation $\left(\mathrm{x}_{8}\right)$, acidification $\left(\mathrm{x}_{9}\right)$, terrestrial eutrophication $\left(\mathrm{x}_{10}\right)$, freshwater eutrophication $\left(\mathrm{x}_{11}\right)$, marine eutrophication $\left(\mathrm{x}_{12}\right)$, land use $\left(\mathrm{x}_{13}\right)$, water resource depletion $\left(\mathrm{x}_{14}\right)$, and, finally, mineral, fossil and renewable resource depletion $\left(\mathrm{x}_{15}\right)$, were grouped together in the Set S2.

In the next stage, reduced and full models were created, and their eco-efficiency scores were calculated. The reduced models were characterized by the following specifications for the input variables:

- $\quad$ Model 1-human toxicity $\left(\mathrm{x}_{1}\right)$;

- Model 2-freshwater ecotoxicity $\left(\mathrm{x}_{2}\right)$.

The full models additionally contain one variable from Set S2. Consequently, many models with different combinations of input variables were generated. The eco-efficiency scores obtained from the full and reduced models are shown in Tables 1 and 2. It should be noted that model 1.2 and model 2.1 have the same specification and, therefore, they give identical results.

As can be seen from the aforementioned tables, the number of eco-efficient DMUs in the full models is the same as the number of eco-efficient DMUs in the reduced models. Moreover, the eco-efficiency results between the full and reduced models do not differ significantly. These observations lead to the conclusion that candidate variables are irrelevant. This is also confirmed by the McNemar test. The $p$-values of the test statistic $\mathrm{Q}_{\mathrm{it}}\left(\mathrm{M}_{\text {full }}-\mathrm{M}_{\mathrm{it}}\right.$; where $\mathrm{M}_{\text {full }}$ is the number of eco-efficient DMUs in full models and $\mathrm{M}_{\mathrm{it}}$ is the number of eco-efficient DMUs in reduced models), which has a distribution $\chi^{2}$ with one degree of freedom, is equal to 1 in each case. Therefore, the null hypothesis $H_{0}: M_{i t}=M_{\text {full }}$ at the significance level $\alpha=0.01$ should not be rejected, and all variables from the S2 set can be omitted.

Summarizing the activities related to the model specification searches, it can be concluded that the assessment of the eco-efficiency of industries should be based on the information from Model $1\left(\mathrm{x}_{1}, \mathrm{y}\right)$ and Model $2\left(\mathrm{x}_{2}, \mathrm{y}\right)$. The average values of the eco-efficiency scores obtained by applying these models are presented in the radar chart of Figure 4 in both a close-up and distant view. The results obtained revealed that only the chemical industry is found to be eco-efficient (eco-efficiency score equal to 1), whereas the remaining industries achieved very low eco-efficiency, particularly the machine industry (0.008), the electrotechnical and electronic industry (0.015), the food industry $(0.025)$, and the building materials industry (0.034).

Considering the environmental profiles of manufacturing in Poland and their ecoefficiency scores, the eco-inefficient industries need to greatly improve their environmental performance to become eco-efficient. They should follow the best practices established by the chemical industry. Thus, based on the weight coefficients derived from the BCC optimization procedure, the percentage exceedances of the environmental impacts were determined for each eco-inefficient industry (Table 3). These hypothetical reductions should be attained while maintaining the current gross value added. For all industries, the obtained results show huge potential for improvement of their environmental performance, with an average of $88 \%$ in the category of human toxicity and $83 \%$ in the category of freshwater ecotoxicity. 
Table 1. Eco-efficiency scores obtained from the full models 1.1-1.14 and the reduced model 1.

\begin{tabular}{|c|c|c|c|c|c|c|c|c|c|c|c|c|c|c|c|}
\hline & \multicolumn{15}{|c|}{ Model Number } \\
\hline & 1 & 1.1 & 1.2 & 1.3 & 1.4 & 1.5 & 1.6 & 1.7 & 1.8 & 1.9 & 1.10 & 1.11 & 1.12 & 1.13 & 1.14 \\
\hline \multirow{2}{*}{ Inputs } & $\mathrm{x}_{1}$ & $\mathrm{x}_{1}$ & $\mathrm{x}_{1}$ & $\mathrm{x}_{1}$ & $\mathrm{x}_{1}$ & $\mathrm{x}_{1}$ & $\mathrm{x}_{1}$ & $\mathrm{x}_{1}$ & $\mathrm{x}_{1}$ & $\mathrm{x}_{1}$ & $\mathrm{x}_{1}$ & $\mathrm{x}_{1}$ & $\mathrm{x}_{1}$ & $\mathrm{x}_{1}$ & $\mathrm{x}_{1}$ \\
\hline & & $\mathrm{x}_{2}$ & $\mathrm{x}_{3}$ & $\mathrm{x}_{4}$ & $\mathrm{x}_{5}$ & $\mathrm{x}_{6}$ & $\mathrm{x}_{7}$ & $\mathrm{x}_{8}$ & $\mathrm{x}_{9}$ & $\mathrm{x}_{10}$ & $\mathrm{x}_{11}$ & $\mathrm{x}_{12}$ & $\mathrm{x}_{13}$ & $\mathrm{x}_{14}$ & $\mathrm{x}_{15}$ \\
\hline & \multicolumn{15}{|c|}{ Eco-efficiency Scores } \\
\hline Industries & $\theta_{1}$ & $\theta_{1.1}$ & $\theta_{1.2}$ & $\theta_{1.3}$ & $\theta_{1.4}$ & $\theta_{1.5}$ & $\theta_{1.6}$ & $\theta_{1.7}$ & $\theta_{1.8}$ & $\theta_{1.9}$ & $\theta_{1.10}$ & $\theta_{1.11}$ & $\theta_{1.12}$ & $\theta_{1.13}$ & $\theta_{1.14}$ \\
\hline Automotive industry & 0.29 & 0.29 & 0.29 & 0.30 & 0.29 & 0.29 & 0.29 & 0.29 & 0.29 & 0.29 & 0.29 & 0.29 & 0.29 & 0.29 & 0.29 \\
\hline $\begin{array}{l}\text { Building materials } \\
\text { industry }\end{array}$ & 0.02 & 0.05 & 0.06 & 0.02 & 0.02 & 0.04 & 0.02 & 0.03 & 0.07 & 0.03 & 0.10 & 0.05 & 0.02 & 0.17 & 0.02 \\
\hline $\begin{array}{l}\text { Electrotechnical and } \\
\text { electronic industry }\end{array}$ & 0.01 & 0.02 & 0.02 & 0.01 & 0.01 & 0.02 & 0.01 & 0.01 & 0.03 & 0.02 & 0.04 & 0.02 & 0.01 & 0.07 & 0.01 \\
\hline Food industry & 0.02 & 0.03 & 0.04 & 0.02 & 0.02 & 0.03 & 0.02 & 0.02 & 0.06 & 0.03 & 0.07 & 0.03 & 0.02 & 0.12 & 0.02 \\
\hline Furniture industry & 0.18 & 0.24 & 0.4 & 0.18 & 0.18 & 0.18 & 0.18 & 0.18 & 0.28 & 0.18 & 0.35 & 0.23 & 0.18 & 0.51 & 0.18 \\
\hline Machine industry & 0.01 & 0.01 & 0.01 & 0.01 & 0.01 & 0.01 & 0.01 & 0.01 & 0.02 & 0.01 & 0.02 & 0.01 & 0.01 & 0.04 & 0.01 \\
\hline Metal industry & 0.21 & 0.37 & 0.43 & 0.21 & 0.21 & 0.33 & 0.21 & 0.26 & 0.54 & 0.30 & 0.63 & 0.37 & 0.23 & 0.89 & 0.21 \\
\hline Paper industry & 0.08 & 0.15 & 0.17 & 0.08 & 0.08 & 0.13 & 0.08 & 0.10 & 0.24 & 0.12 & 0.31 & 0.15 & 0.09 & 0.50 & 0.08 \\
\hline $\begin{array}{l}\text { Textile and clothing } \\
\text { industry }\end{array}$ & 0.24 & 0.27 & 0.24 & 0.24 & 0.24 & 0.27 & 0.24 & 0.24 & 0.24 & 0.24 & 0.29 & 0.24 & 0.24 & 0.42 & 0.24 \\
\hline Wood industry & 0.14 & 0.22 & 0.17 & 0.14 & 0.14 & 0.20 & 0.14 & 0.15 & 0.25 & 0.17 & 0.31 & 0.20 & 0.15 & 0.32 & 0.14 \\
\hline
\end{tabular}


Table 2. Eco-efficiency scores obtained from the full models 2.1-2.14 and the reduced model 2.

\begin{tabular}{|c|c|c|c|c|c|c|c|c|c|c|c|c|c|c|c|}
\hline & \multicolumn{15}{|c|}{ Model Number } \\
\hline & 2 & 2.1 & 2.2 & 2.3 & 2.4 & 2.5 & 2.6 & 2.7 & 2.8 & 2.9 & 2.10 & 2.11 & 2.12 & 2.13 & 2.14 \\
\hline \multirow{2}{*}{ Inputs } & $\mathrm{x}_{2}$ & $\mathrm{x}_{2}$ & $\mathrm{x}_{2}$ & $\mathrm{x}_{2}$ & $\mathrm{x}_{2}$ & $\mathrm{x}_{2}$ & $\mathrm{x}_{2}$ & $x_{2}$ & $x_{2}$ & $x_{2}$ & $\mathrm{x}_{2}$ & $\mathrm{x}_{2}$ & $x_{2}$ & $x_{2}$ & $x_{2}$ \\
\hline & & $\mathrm{x}_{1}$ & $x_{3}$ & $\mathrm{x}_{4}$ & $x_{5}$ & $x_{6}$ & $x_{7}$ & $\mathrm{x}_{8}$ & $\mathrm{x}_{9}$ & $x_{10}$ & $x_{11}$ & $x_{12}$ & $x_{13}$ & $\mathrm{x}_{14}$ & $\mathrm{x}_{15}$ \\
\hline & \multicolumn{15}{|c|}{ Eco-efficiency Scores } \\
\hline Industries & $\theta_{2}$ & $\theta_{2.1}$ & $\theta_{2.2}$ & $\theta_{2.3}$ & $\theta_{2.4}$ & $\theta_{2.5}$ & $\theta_{2.6}$ & $\theta_{2.7}$ & $\theta_{2.8}$ & $\theta_{2.9}$ & $\theta_{2.10}$ & $\theta_{2.11}$ & $\theta_{2.12}$ & $\theta_{2.13}$ & $\theta_{2.14}$ \\
\hline Automotive industry & 0.29 & 0.29 & 0.29 & 0.30 & 0.29 & 0.29 & 0.29 & 0.29 & 0.29 & 0.29 & 0.29 & 0.29 & 0.29 & 0.29 & 0.29 \\
\hline $\begin{array}{l}\text { Building materials } \\
\text { industry }\end{array}$ & 0.05 & 0.05 & 0.06 & 0.05 & 0.05 & 0.05 & 0.05 & 0.05 & 0.07 & 0.05 & 0.10 & 0.05 & 0.05 & 0.17 & 0.05 \\
\hline Chemical industry & 1 & 1 & 1 & 1 & 1 & 1 & 1 & 1 & 1 & 1 & 1 & 1 & 1 & 1 & 1 \\
\hline $\begin{array}{l}\text { Electrotechnical and } \\
\text { electronic industry }\end{array}$ & 0.02 & 0.02 & 0.02 & 0.02 & 0.02 & 0.02 & 0.02 & 0.02 & 0.03 & 0.02 & 0.04 & 0.02 & 0.02 & 0.07 & 0.02 \\
\hline Food industry & 0.03 & 0.03 & 0.04 & 0.03 & 0.03 & 0.03 & 0.03 & 0.03 & 0.06 & 0.03 & 0.07 & 0.03 & 0.03 & 0.12 & 0.03 \\
\hline Furniture industry & 0.24 & 0.24 & 0.40 & 0.24 & 0.24 & 0.24 & 0.24 & 0.24 & 0.28 & 0.24 & 0.35 & 0.24 & 0.24 & 0.51 & 0.24 \\
\hline Machine industry & 0.01 & 0.01 & 0.01 & 0.01 & 0.01 & 0.01 & 0.01 & 0.01 & 0.02 & 0.01 & 0.02 & 0.01 & 0.01 & 0.04 & 0.01 \\
\hline Metal industry & 0.37 & 0.37 & 0.43 & 0.37 & 0.37 & 0.37 & 0.37 & 0.37 & 0.54 & 0.37 & 0.63 & 0.37 & 0.37 & 0.89 & 0.37 \\
\hline Paper industry & 0.15 & 0.15 & 0.17 & 0.15 & 0.15 & 0.15 & 0.15 & 0.15 & 0.24 & 0.15 & 0.31 & 0.15 & 0.15 & 0.50 & 0.15 \\
\hline $\begin{array}{l}\text { Textile and clothing } \\
\text { industry }\end{array}$ & 0.27 & 0.27 & 0.27 & 0.27 & 0.27 & 0.27 & 0.27 & 0.27 & 0.27 & 0.27 & 0.29 & 0.27 & 0.27 & 0.42 & 0.27 \\
\hline Wood industry & 0.22 & 0.22 & 0.22 & 0.22 & 0.22 & 0.22 & 0.22 & 0.22 & 0.25 & 0.22 & 0.31 & 0.22 & 0.22 & 0.32 & 0.22 \\
\hline
\end{tabular}



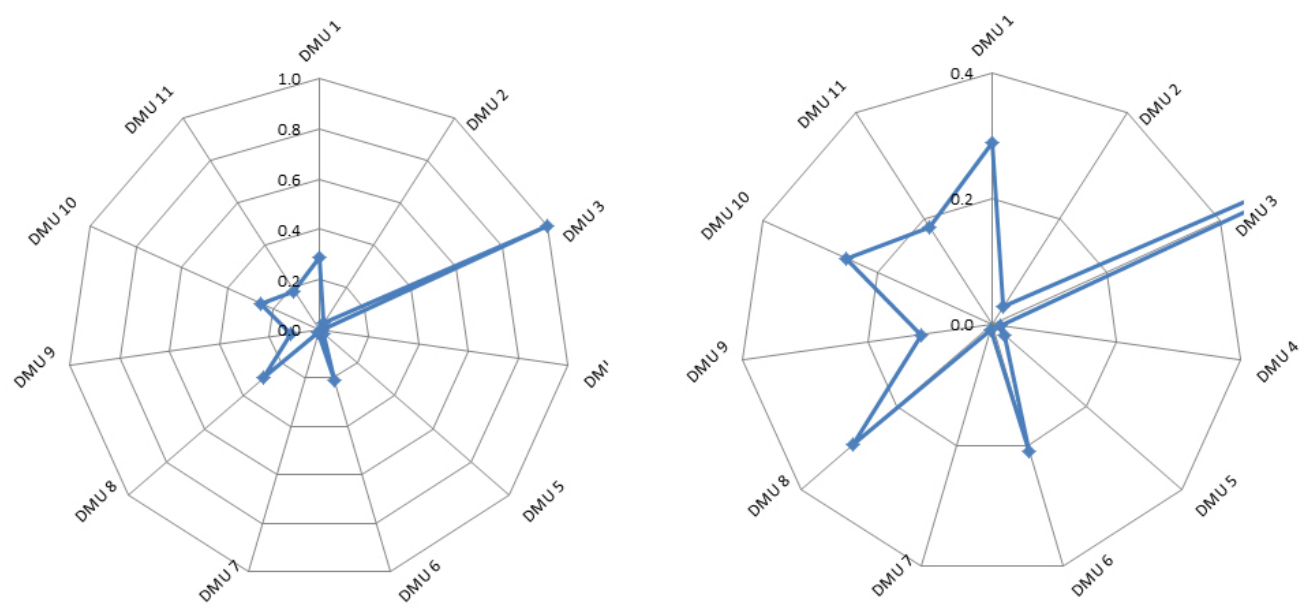

Figure 4. Eco-efficiency of manufacturing in Poland (DMU 1-automotive industry; DMU 2-building materials industry; DMU 3-chemical industry; DMU 4-electrotechnical and electronic industry; DMU 5-food industry; DMU 6-furniture industry; DMU 7-machine industry; DMU 8-metal industry; DMU 9-paper industry; DMU 10—textile and clothing industry; DMU 11—wood industry).

Table 3. Percentage potential reductions in environmental impacts.

\begin{tabular}{|c|c|c|c|c|c|c|c|c|c|c|}
\hline Impact Category & 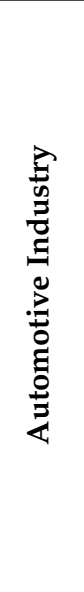 & 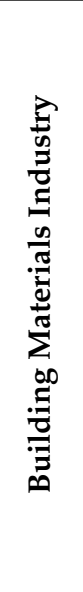 & 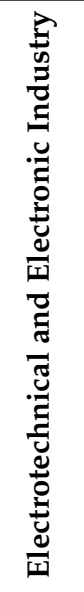 & 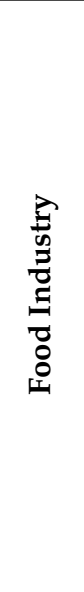 & 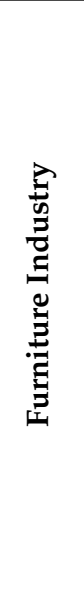 & 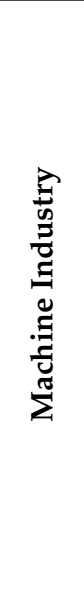 & 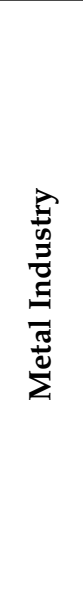 & 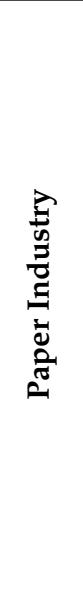 & 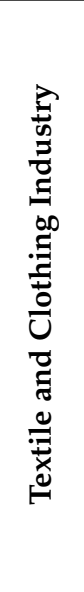 & 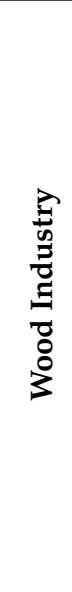 \\
\hline Human toxicity & 70.7 & 97.7 & 99.0 & 98.3 & 82.2 & 99.4 & 78.9 & 92.4 & 76.3 & 85.6 \\
\hline Freshwater ecotoxicity & 71.4 & 95.5 & 98.0 & 96.6 & 75.6 & 98.9 & 62.6 & 84.9 & 72.9 & 77.8 \\
\hline
\end{tabular}

\section{Discussion}

The results of the study indicate that most of the manufacturing industries in Poland are operating under conditions of eco-inefficiency. In fact, only the chemical industry is $100 \%$ eco-efficient. The remaining industries do not achieve efficiency even at the level of $50 \%$. Therefore, the potential to improve their eco-efficiency is very high. This can be accomplished by either decreasing the environmental pressure or increasing the product value (gross value added). Thus, target environmental impact profiles were established for eco-inefficient industries. Although they cannot be taken literally, they show how much work Polish industries have to do in relation to the chemical industry in order to move from unsustainable to sustainable production. In addition, they provide a valuable insight for policymakers and a scientific basis for developing more effective strategies to accelerate the transition toward a circular economy.

Only harmonized and efficacious activities to increase eco-efficiency will allow the introduction of a more resource-efficient and circular economy. The improvement of ecoefficiency can be accomplished by either decreasing the inputs or increasing the outputs. 
Consequently, there is no one-size-fits-all solution for improving the eco-efficiency of manufacturing in Poland. Instead, there is always an individual path for a manufacturing industry depending upon its environmental profile and gross value added. For example, the main problem of the food industry is the large amount of gases and dusts produced and emitted into the atmosphere. Emissions can be reduced by using new low emission technologies. Another important issue is the amount of water used, which should be minimized as much as possible, e.g., through recycling and reuse [33]. The metal industry, including the production of iron and steel, has a negative impact on the environment due to excessive greenhouse gas emissions and energy consumption. One way to improve the situation would be, for example, to produce pig iron without the use of coke [34]. Finally, the building materials industry, including cement production, generates gas and dust pollutants and thus contributes to global warming. The vast majority of these emissions are the so-called process emissions that cannot be eliminated. Despite technological barriers, a number of actions can be implemented to address progressive reduction of emissions, such as improving the efficiency of heat use, installing modern automation, as well as replacing some of the natural resources with waste and by-products from other industrial processes [35].

Regardless of the type of activity, Polish industries have many opportunities to build pro-ecological business models. In general, the successful transformation of intensive production methods into less resource-intensive and/or low-emission ones, the reincorporation of waste into production processes, the implementation of environmental management systems, and the introduction of new business strategies built on life cycle thinking (LCT) should be voluntary targets for activities. It should also be noted that even the selection of a set of reasonable parameters for manufacturing systems is of great importance in reducing material and energy consumption, and thus achieving sustainable manufacturing [36].

Polish industries should follow the patterns established by the chemical industry. Currently, increasing numbers of chemical companies are implementing modernization programs related to the construction of modern production installations, as well as introducing requirements to reduce the consumption of raw materials and energy. Although the chemical industry is burdened with some of the highest regulatory costs, it continues to improve its pro-environmental performance without slowing down its pace of development. In 2019, the chemical industry in Poland remained the second largest in terms of production rate after the food industry, and the value of its sold production was higher by $40 \%$ compared to 2010 . At the same time, energy consumption has halved in the last 20 years. In addition, chemical companies have been undertaking activities related to the protection of atmospheric air and climate for years, to which as much as $85 \%$ of the funds of all ecological investments are allocated. With environmental and economic issues in mind, it can be concluded that the chemical industry is far ahead of other industries in Poland [37].

\section{Conclusions}

Climate change and widespread degradation of natural resources undoubtedly indicate that the time is ripe for addressing the new challenges of producing more and better with less. In practice, this means making the necessary investments to ensure the production of goods while reducing waste and emissions, minimizing the consumption of material and energy resources, and reusing materials multiple times. However, launching actions in line with the goals of sustainable production and the circular economy requires the implementation of an effective and efficient approach to assess the results. This study proposes the use of the LCA+DEA methodology as a tool to measure eco-efficiency at the sector level to support sustainable development.

The conducted research on the eco-efficiency performance of manufacturing in Poland contains two types of contributions. First, from a methodological viewpoint, it confirmed the high applicability of the LCA+DEA approach for measuring eco-efficiency at the sector level. There are, though, many arguments for such a methodological proceeding, including 
the quantification of eco-efficiency on environmental impacts considered from the life cycle perspective and not operational input-output tables, as well as the ability to analyze product systems-in our case, industries-of structural and operational heterogeneity, but functional homogeneity. Thus, this study has methodological implications for the structuring of inventory tables, selection of the functional unit, and, finally, designing a DEA model for the quantitative analysis of eco-efficiency of manufacturing.

Second, from a practical viewpoint, the research revealed that despite continuous endeavors to decrease environmental impacts, manufacturing in Poland still faces a challenge in reconciling high environmental and economic performance. However, the research has shown that only the chemical industry is $100 \%$ eco-efficient, whereas the remaining industries have considerable room for the improvement of their eco-efficiency. This proves a significant mismatch between the applied manufacturing practices and the current market and legal expectations regarding environmental protection and climate impacts. This implies that manufacturing in Poland requires more financial and technical support to establish and optimize sustainability practices. Therefore, the research results can be the basis for creating the necessary guidelines to change the environmental behavior of companies and introduce new practices, including green technology innovations and environmental management systems.

Although the current research provides a valuable insight into the eco-efficiency measurement of manufacturing in Poland, it is not free of limitations. These stem from the concept of eco-efficiency itself and the employed methodology. However, eco-efficiency does not have to result in the absolute improvement of environmental performance, since it addresses the relationship between environmental performance and economic output. Thus, for instance, as long as the growth rate of economic output is higher than the growth rate of environmental performance, even if both are growing, eco-efficiency will increase. As a result, eco-efficiency should not be used as a single measure, but rather as one of a set of measures of the status and progress towards a sustainable manufacturing. Finally, the joint application of LCA+DEA is a powerful tool in eco-efficiency measurement, but the obtained LCA+DEA results may vary according to the kind of LCI, economic data, and the functional unit involved, as well as the DEA model. Subsequent studies should expand the static and cross-sectional frameworks in this paper and perform comparative analyses over a longer time frame and using other DEA models.

Author Contributions: Conceptualization, A.M.-J. and M.R.-B.; methodology, LCA analysis, M.R.-B.; DEA analysis, A.M.-J.; investigation, M.R.-B. and A.M.-J.; data curation, A.M.-J.; writing-original draft preparation, A.M.-J. and M.R.-B.; writing—review and editing, A.M.-J. and M.R.-B.; visualization, A.M.-J. and M.R.-B.; supervision, M.R.-B. All authors have read and agreed to the published version of the manuscript.

Funding: This research received no external funding.

Institutional Review Board Statement: Not applicable.

Informed Consent Statement: Not applicable.

Data Availability Statement: https://stat.gov.pl/.

Conflicts of Interest: The authors declare no conflict of interest. 


\section{Appendix A}

Table A1. Simplified LCI table of manufacturing in Poland (base year of 2019).

\begin{tabular}{|c|c|c|c|c|c|c|c|c|c|c|c|c|c|c|c|c|c|c|}
\hline \multirow[b]{2}{*}{ Industries } & \multirow{2}{*}{$\begin{array}{c}\text { Electricity } \\
\text { in GWh }\end{array}$} & \multirow{2}{*}{$\begin{array}{c}\text { Hard Coal } \\
\begin{array}{c}\text { in } \\
\text { Thousands } \\
\text { of } \mathbf{M g}\end{array} \\
\end{array}$} & Natural Gas & Water & $\begin{array}{l}\text { Coniferous } \\
\text { Sawnwood }\end{array}$ & $\begin{array}{l}\begin{array}{l}\text { Particle } \\
\text { Boards }\end{array} \\
\end{array}$ & $\begin{array}{l}\text { Paper and } \\
\text { Paperboard }\end{array}$ & Plastics & Cement & $\begin{array}{c}\text { Steel } \\
\text { Products }\end{array}$ & Wastewater & $\begin{array}{l}\text { Sulphur } \\
\text { Dioxide }\end{array}$ & $\begin{array}{c}\text { Carbon } \\
\text { Oxide }\end{array}$ & $\begin{array}{c}\text { Carbon } \\
\text { Dioxide }\end{array}$ & Particulates & Waste & $\begin{array}{c}\begin{array}{c}\text { Gross Value } \\
\text { Added }\end{array} \\
\text {. }\end{array}$ & $\begin{array}{c}\text { Sold } \\
\text { Production }\end{array}$ \\
\hline & & & \multicolumn{2}{|c|}{ in $\mathrm{hm}^{3}$} & \multicolumn{2}{|c|}{ in $\mathrm{dam}^{3}$} & \multicolumn{4}{|c|}{ in Thousands of $\mathrm{Mg}$} & in $\mathrm{hm}^{3}$ & \multicolumn{5}{|c|}{ in Thousands of $\mathrm{Mg}$} & \multicolumn{2}{|c|}{ in Million EUR } \\
\hline $\begin{array}{l}\text { Automotive industry } \\
\text { Rulitding }\end{array}$ & 3294 & 29 & 157 & 1.3 & 9.9 & 61.5 & 13.2 & 92.9 & 2.4 & $115,597.7$ & 1.7 & 0.6 & 3.6 & 186.6 & 0.4 & 848 & $55,932.5$ & 819,298 \\
\hline $\begin{array}{l}\text { Building materials sindustry } \\
\text { Chemical industry }\end{array}$ & $\begin{array}{l}5687 \\
16106\end{array}$ & $\begin{array}{c}839 \\
14,154\end{array}$ & 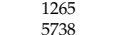 & $\begin{array}{l}12.6 \\
3517\end{array}$ & $\begin{array}{c}28.5 \\
55\end{array}$ & ${ }_{44.8}^{10.8}$ & $\begin{array}{l}80.9 \\
98\end{array}$ & $\begin{array}{r}26.2 \\
2453.3\end{array}$ & $\begin{array}{l}8621.1 \\
2708\end{array}$ & $\begin{array}{l}1044.3 \\
136977\end{array}$ & $\begin{array}{l}49.5 \\
3045\end{array}$ & & 62.9 & $\begin{array}{l}17,346.6 \\
228525\end{array}$ & 3 & 3496.2 & $\begin{array}{r}97,900.9 \\
070119\end{array}$ & $277,900.7$ \\
\hline $\begin{array}{l}\text { Electrotechnical and electronic industry } \\
\text { Elical }\end{array}$ & $\begin{array}{l}16,106 \\
1562\end{array}$ & $\begin{array}{l}14,154 \\
4\end{array}$ & $\begin{array}{c}5738 \\
58\end{array}$ & $\begin{array}{l}351.7 \\
1.1\end{array}$ & $\begin{array}{l}55 \\
6.4\end{array}$ & ${ }_{7.2}^{4.2}$ & ${ }_{22}^{98}$ & $\begin{array}{l}2455.3 \\
208\end{array}$ & $\begin{array}{l}270.8 \\
12.2\end{array}$ & $\begin{array}{l}13,697.7 \\
14,689.4\end{array}$ & $\begin{array}{ccc}30.9 \\
0.8\end{array}$ & 18.6 & 20.5 & $22,825.5$ & $\begin{array}{l}3.6 \\
01\end{array}$ & $\begin{array}{l}6135 \\
195.7\end{array}$ & 70,802 & $\begin{array}{l}1,144,622 \\
480202\end{array}$ \\
\hline 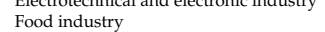 & 7539 & $\stackrel{4}{1088}$ & $\begin{array}{c}58 \\
1007\end{array}$ & $\begin{array}{l}1.1 \\
117.4\end{array}$ & $\begin{array}{l}6.4 \\
3.7\end{array}$ & 0.1 & 157.9 & $\begin{array}{l}20.3 \\
16.3\end{array}$ & $\frac{12.2}{2}$ & $\begin{array}{c}14,098.4 \\
463.6\end{array}$ & $\begin{array}{lll}0.8 & 8 \\
94.1 & & \end{array}$ & $\begin{array}{l}0.2 \\
10.9\end{array}$ & 7.4 & $\begin{aligned} 18.4 \\
4367.2\end{aligned}$ & $\begin{array}{l}0.1 \\
1.9\end{array}$ & 3056.6 & $291,048.5$ & $\begin{array}{l}489,02.9 \\
1,175,286\end{array}$ \\
\hline Furniture industry & 1110 & 4 & 16 & 0.4 & 1010.3 & 4186.7 & 117.5 & 2.2 & 0.4 & $21,372.4$ & 0.3 & 0.3 & 0.4 & 121.5 & 0.2 & 558.3 & $50,590.4$ & $216,998.7$ \\
\hline Machine industry & 1225 & 22 & 49 & 1.1 & 18.3 & 15.9 & 4.3 & 9.3 & 1.8 & 57,664 & 1.7 & 0.2 & 0.5 & 93.8 & 0.2 & 266.4 & $58,475.3$ & $236,176.1$ \\
\hline $\begin{array}{l}\text { Metal industry } \\
\text { Paperindsustry }\end{array}$ & $\begin{array}{c}10,956 \\
4711\end{array}$ & $\begin{array}{l}1479 \\
576\end{array}$ & 984 & 30.2 & 65 & 56.1 & $\begin{array}{r}55.2 \\
44125\end{array}$ & 32.8 & 9 & 336,666 & 138.1 & 8.5 & 130.6 & 8338.3 & 3.2 & 9911.3 & $84,751.7$ & $800,212.6$ \\
\hline $\begin{array}{l}\text { Paper industry } \\
\text { Textile and clothing industry }\end{array}$ & 4711 & 576 & 341 & 100.5 & $0_{0.1}^{0.1}$ & $\begin{array}{r}55 \\
224\end{array}$ & ${ }^{4412.5}$ & ${ }_{471}^{29.8}$ & ${ }_{0}^{0}$ & $\begin{array}{l}196.4 \\
13212\end{array}$ & 92.4 & 1.9 & 2.1 & $\begin{array}{l}4624.9 \\
32.7\end{array}$ & 0.5 & 1431.7 & $\begin{array}{l}171,870.8 \\
270805\end{array}$ & $207,610.1$ \\
\hline $\begin{array}{l}\text { Texter and coming inastry } \\
\text { Wood industr }\end{array}$ & $\begin{array}{l}5514 \\
2594\end{array}$ & $\begin{array}{l}14 \\
64\end{array}$ & 54 & $\begin{array}{l}4.6 \\
5.2\end{array}$ & $\begin{array}{l}0.8 \\
4611.4\end{array}$ & $\begin{array}{c}2.24 \\
1740.9\end{array}$ & $\begin{array}{l}20.1 \\
48.1\end{array}$ & ${ }_{0.1}^{4 l .1}$ & 1.6 & $\begin{array}{l}1521.2 \\
1299.7\end{array}$ & $\begin{array}{l}4.4 \\
1.9\end{array}$ & 0.6 & 4.1 & $\begin{array}{l}3.7 .3 \\
1769.3\end{array}$ & 1.4 & $\begin{array}{l}10.6 \\
1065.8\end{array}$ & $\begin{array}{l}27,800 \\
236,777.9\end{array}$ & $\begin{array}{l}13,5130 \\
184,579.7\end{array}$ \\
\hline
\end{tabular}

\section{Appendix B}

Table A2. Environmental profiles of manufacturing in Poland.

\begin{tabular}{|c|c|c|c|c|c|c|c|c|c|c|c|c|}
\hline Impact Category & Unit & $\begin{array}{l}\text { Automotive } \\
\text { Industry }\end{array}$ & $\begin{array}{c}\text { Building } \\
\text { Materials } \\
\text { Industry }\end{array}$ & $\begin{array}{l}\text { Chemical } \\
\text { Industry }\end{array}$ & $\begin{array}{l}\text { Electrotechnical } \\
\text { and Electronic } \\
\text { Industry }\end{array}$ & $\begin{array}{c}\text { Food } \\
\text { Industry }\end{array}$ & $\begin{array}{l}\text { Furniture } \\
\text { Industry }\end{array}$ & $\begin{array}{l}\text { Machine } \\
\text { Industry }\end{array}$ & $\begin{array}{c}\text { Metal } \\
\text { Industry }\end{array}$ & $\begin{array}{l}\text { Paper } \\
\text { Industry }\end{array}$ & $\begin{array}{l}\text { Textile and } \\
\text { Clothing } \\
\text { Industry }\end{array}$ & $\begin{array}{l}\text { Wood } \\
\text { Industry }\end{array}$ \\
\hline Climate change & $\mathrm{kg} \mathrm{CO} 2 \mathrm{eq}$ & 5324.898 & 2166.816 & 1187.779 & 1200.695 & 205.908 & 3700.306 & 9174.010 & $16,076.155$ & 1779.453 & 475.382 & 519.159 \\
\hline Ozone depletion & $\begin{array}{c}\mathrm{kg} \mathrm{CFC}-11 \\
\text { eq }\end{array}$ & 0.0002084 & 0.0000114 & 0.0000217 & 0.0000450 & 0.0000024 & 0.0001587 & 0.0003600 & 0.0006218 & 0.0000082 & 0.0000157 & 0.0000273 \\
\hline Particulate matter & $\mathrm{kg}$ PM2.5 eq & 4.461 & 0.386 & 0.526 & 0.972 & 0.073 & 3.463 & 7.704 & 13.324 & 0.380 & 0.349 & 0.520 \\
\hline Ionizing radiation $\mathrm{HH}$ & kBq U235 eq & 123.692 & 13.562 & 17.605 & 27.485 & 3.597 & 101.301 & 213.133 & 369.768 & 12.732 & 10.873 & 19.775 \\
\hline Ionizing radiation E & CTUe & 0.0005235 & 0.0000455 & 0.0000663 & 0.0001150 & 0.0000115 & 0.0004186 & 0.0009030 & 0.0015637 & 0.0000402 & 0.0000434 & 0.0000715 \\
\hline $\begin{array}{l}\text { Photochemical ozone } \\
\text { formation }\end{array}$ & $\begin{array}{c}\mathrm{kg} \text { NMVOC } \\
\text { eq }\end{array}$ & 17.658 & 2.308 & 2.530 & 3.939 & 0.386 & 13.564 & 30.441 & 52.825 & 4.638 & 1.508 & 2.520 \\
\hline Acidification & molc $\mathrm{H}+$ eq & 21.415 & 5.966 & 4.681 & 4.997 & 1.183 & 16.269 & 36.766 & 64.227 & 8.062 & 2.201 & 4.273 \\
\hline $\begin{array}{l}\text { Terrestrial } \\
\text { eutrophication }\end{array}$ & molc $\mathrm{N}$ eq & 48.200 & 6.782 & 7.498 & 10.857 & 1.275 & 36.636 & 83.035 & 143.907 & 13.226 & 4.308 & 7.337 \\
\hline $\begin{array}{l}\text { Freshwater } \\
\text { eutrophication }\end{array}$ & $\mathrm{kg}$ P eq & 2.1204907 & 0.5415645 & 0.5101029 & 0.5067437 & 0.1589907 & 1.5818002 & 3.6274955 & 6.3663725 & 0.5600210 & 0.2514763 & 0.4565701 \\
\hline $\begin{array}{l}\text { Marine eutrophication } \\
\text { Freshwater ecotoxicity }\end{array}$ & $\begin{array}{l}\mathrm{kg} \mathrm{Neq} \\
\text { CTUe }\end{array}$ & $\begin{array}{l}4.9703944 \\
46,868.798\end{array}$ & $\begin{array}{l}0.7678334 \\
5854.140\end{array}$ & $\begin{array}{l}0.8801610 \\
7135.210\end{array}$ & $\begin{array}{l}1.1219244 \\
10,499.664\end{array}$ & $\begin{array}{c}0.1725298 \\
1587.208\end{array}$ & $\begin{array}{l}3.7487581 \\
35,268.574\end{array}$ & $\begin{array}{l}8.5611658 \\
80,705.000\end{array}$ & $\begin{array}{l}14.903779 \\
140,179.83\end{array}$ & $\begin{array}{l}1.3847954 \\
5554.734\end{array}$ & $\begin{array}{l}0.4614381 \\
4249.285\end{array}$ & $\begin{array}{l}0.7579081 \\
6501.409\end{array}$ \\
\hline Land use & $\operatorname{kg} C$ deficit & 4769.771 & 363.095 & 576.888 & 1040.548 & 88.898 & 4626.592 & 8231.108 & $14,245.282$ & 330.961 & 390.481 & 1010.810 \\
\hline $\begin{array}{l}\text { Water resource } \\
\text { depletion }\end{array}$ & m3 water eq & 47.442 & 13.620 & 18.023 & 11.502 & 5.766 & 34.639 & 81.123 & 142.897 & 23.268 & 6.464 & 11.228 \\
\hline $\begin{array}{l}\text { Mineral, fossil, and ren } \\
\text { resource depletion }\end{array}$ & $\mathrm{kg} \mathrm{Sb} \mathrm{eq}$ & 0.0772846 & 0.0035071 & 0.0075919 & 0.0166082 & 0.0005587 & 0.0574274 & 0.1336297 & 0.2305447 & 0.0036307 & 0.0056401 & 0.0062291 \\
\hline
\end{tabular}




\section{Appendix C}

Table A3. Normalized environmental profiles of manufacturing in Poland.

\begin{tabular}{|c|c|c|c|c|c|c|c|c|c|c|c|c|}
\hline Impact Category & Unit & $\begin{array}{l}\text { Automotive } \\
\text { Industry }\end{array}$ & $\begin{array}{c}\text { Building } \\
\text { Materials } \\
\text { Industry }\end{array}$ & $\begin{array}{l}\text { Chemical } \\
\text { Industry }\end{array}$ & $\begin{array}{l}\text { Electrotechnical } \\
\text { and Electronic } \\
\text { Industry }\end{array}$ & $\begin{array}{c}\text { Food } \\
\text { Industry }\end{array}$ & $\begin{array}{l}\text { Furniture } \\
\text { Industry }\end{array}$ & $\begin{array}{l}\text { Machine } \\
\text { Industry }\end{array}$ & $\begin{array}{l}\text { Metal } \\
\text { Industry }\end{array}$ & $\begin{array}{l}\text { Paper } \\
\text { Industry }\end{array}$ & $\begin{array}{l}\text { Textile and } \\
\text { Clothing } \\
\text { Industry }\end{array}$ & $\begin{array}{l}\text { Wood } \\
\text { Industry }\end{array}$ \\
\hline Climate change & PE & 0.578 & 0.235 & 0.129 & 0.130 & 0.022 & 0.401 & 0.995 & 1.744 & 0.193 & 0.052 & 0.056 \\
\hline Ozone depletion & $\mathrm{PE}$ & 0.010 & 0.001 & 0.001 & 0.002 & 0.000 & 0.007 & 0.017 & 0.029 & 0.000 & 0.001 & 0.001 \\
\hline Human toxicity & $\mathrm{PE}$ & 32.684 & 2.292 & 3.758 & 7.118 & 0.542 & 23.333 & 56.439 & 97.606 & 1.850 & 2.569 & 3.042 \\
\hline Particulate matter & PE & 1.174 & 0.102 & 0.138 & 0.256 & 0.019 & 0.911 & 2.027 & 3.506 & 0.100 & 0.092 & 0.137 \\
\hline Ionizing radiation $\mathrm{HH}$ & $\mathrm{PE}$ & 0.109 & 0.012 & 0.016 & 0.024 & 0.003 & 0.090 & 0.189 & 0.327 & 0.011 & 0.010 & 0.018 \\
\hline Ionizing radiation $\mathrm{E}$ & PE & 0.000 & 0.000 & 0.000 & 0.000 & 0.000 & 0.000 & 0.000 & 0.000 & 0.000 & 0.000 & 0.000 \\
\hline $\begin{array}{l}\text { Photochemical ozone } \\
\text { formation }\end{array}$ & PE & 0.557 & 0.073 & 0.080 & 0.124 & 0.012 & 0.428 & 0.960 & 1.666 & 0.146 & 0.048 & 0.080 \\
\hline Acidification & PE & 0.453 & 0.126 & 0.099 & 0.106 & 0.025 & 0.344 & 0.777 & 1.358 & 0.170 & 0.047 & 0.090 \\
\hline $\begin{array}{l}\text { Terrestrial } \\
\text { eutrophication }\end{array}$ & PE & 0.274 & 0.039 & 0.043 & 0.062 & 0.007 & 0.208 & 0.472 & 0.818 & 0.075 & 0.024 & 0.042 \\
\hline $\begin{array}{l}\text { Freshwater } \\
\text { eutrophication }\end{array}$ & PE & 1.433 & 0.366 & 0.345 & 0.342 & 0.107 & 1.069 & 2.451 & 4.302 & 0.378 & 0.170 & 0.308 \\
\hline Marine eutrophication & $\mathrm{PE}$ & 0.294 & 0.045 & 0.052 & 0.066 & 0.010 & 0.222 & 0.507 & 0.882 & 0.082 & 0.027 & 0.045 \\
\hline Freshwater ecotoxicity & $\begin{array}{l}\mathrm{PE} \\
\mathrm{PE}\end{array}$ & $\begin{array}{l}5.363 \\
0.064\end{array}$ & $\begin{array}{l}0.670 \\
0.005\end{array}$ & $\begin{array}{l}0.816 \\
0.008\end{array}$ & $\begin{array}{l}1.201 \\
0.014\end{array}$ & $\begin{array}{l}0.182 \\
0.001\end{array}$ & $\begin{array}{l}4.035 \\
0.062\end{array}$ & $\begin{array}{l}9.234 \\
0.110\end{array}$ & $\begin{array}{c}16.039 \\
0.190\end{array}$ & 0.636 & 0.486 & 0.744 \\
\hline $\begin{array}{l}\text { Land use } \\
\text { Water resource }\end{array}$ & PE & 0.064 & 0.167 & 0.221 & 0.141 & 0.071 & 0.062 & 0.997 & 0.190 & 0.004 & 0.005 & 0.014 \\
\hline $\begin{array}{l}\text { depletion } \\
\text { Mineral, fossil, and ren }\end{array}$ & $P E$ & 0.583 & 0.167 & 0.221 & 0.141 & 0.071 & 0.426 & 0.997 & 1.755 & 0.286 & 0.079 & 0.138 \\
\hline resource depletion & PE & 0.765 & 0.035 & 0.075 & 0.164 & 0.006 & 0.569 & 1.323 & 2.283 & 0.036 & 0.056 & 0.062 \\
\hline
\end{tabular}




\section{References}

1. WBCSD (World Business Council for Sustainable Development). Eco-Efficiency Learning Module. 2006. Available online: http:/ / docs.wbcsd.org/2006/08/EfficiencyLearningModule.pdf (accessed on 23 November 2020).

2. UN ESCAP (United Nations Economic and Social Commission for Asian and the Pacific). Eco-Efficiency Indicators: Measuring Resource-Use Efficiency and the Impact of Economic Activities on the Environment. 2009. Available online: https: / / sustainabledevelopment.un.org/content/documents/785eco.pdf (accessed on 13 July 2021).

3. ISO (International Standard Organisation). International Standard ISO 14045. Environmental Management-Eco-Efficiency Assessment of Product Systems_-Principles, Requirements and Guidelines; ISO Copyright Office: Geneva, Switzerland, 2012.

4. Rybaczewska-Błażejowska, M.; Masternak-Janus, A. Eco-efficiency assessment of Polish regions: Joint application of life cycle assessment and data envelopment analysis. J. Clean. Prod. 2018, 172, 1180-1192. [CrossRef]

5. Ullah, A.; Perret, S.R.; Gheewala, S.H.; Soni, P. Eco-efficiency of cotton-cropping systems in Pakistan: An integrated approach of life cycle assessment and data envelopment analysis. J. Clean. Prod. 2016, 134, 623-632. [CrossRef]

6. Egilemez, G.; Kucukvar, M.; Tatari, O. Sustainability assessment of U.S. manufacturing sectors: An economic input output-based frontier approach. J. Clean. Prod. 2013, 53, 91-102. [CrossRef]

7. Egilmez, G.; Kucukvar, M.; Tatari, O.; Bhuttac, M.K.S. Supply chain sustainability assessment of the US food manufacturing sectors: A life cycle-based frontier approach. Resour. Conserv. Recycl. 2014, 82, 8-20. [CrossRef]

8. Zurano-Cervelló, P.; Pozo, C.; Mateo-Sanz, J.M.; Jiménez, L.; Guillén-Gosálbez, G. Eco-efficiency assessment of EU manufacturing sectors combining input-output tables and data envelopment analysis following production and consumption-based accounting approaches. J. Clean. Prod. 2018, 174, 1161-1189. [CrossRef]

9. Xing, Z.; Wang, J.; Zhang, J. Expansion of environmental impact assessment for eco-efficiency evaluation of China's economic sectors: An economic input-output based frontier approach. Sci. Total Environ. 2018, 635, 284-293. [CrossRef] [PubMed]

10. Masternak-Janus, A. Zastosowanie ekoefektywności do oceny społecznej odpowiedzialności przedsiębiorstw przetwórstwa przemysłowego $\mathrm{w}$ Polsce [Application of eco-efficiency to the assessment of social responsibility in processing industry enterprises in Poland]. J. Mark. Mark. Stud. 2017, 11, 345-355.

11. Avadi, Á.; Vázquez-Rowe, I.; Fréon, P. Eco-efficiency assessment of the Peruvian anchoveta steel and wooden fleets using the LCA+DEA framework. J. Clean. Prod. 2014, 70, 118-131. [CrossRef]

12. Rybaczewska-Błażejowska, M. Eco-Innovation and Eco-Efficiency in the Frame of Life Cycle Assessment; Publishing House of the Kielce University of Technology: Kielce, Poland, 2019; pp. 85-123.

13. Vázquez-Rowe, I.; Iribarren, D. Review of Life-Cycle Approaches Coupled with Data Envelopment Analysis: Launching the CFP + DEA Method for Energy Policy Making. Sci. World J. 2015. Available online: https://www.researchgate.net/publication/2717 22920_Review_of_Life-Cycle_Approaches_Coupled_with_Data_Envelopment_Analysis_Launching_the_CFP_DEA_Method_ for_Energy_Policy_Making (accessed on 19 November 2021).

14. ISO (International Standard Organisation). International Standard ISO 14040. Environmental Management-Life Cycle AssessmentPrinciples and Framework; ISO Copyright Office: Geneva, Switzerland, 2006.

15. ISO (International Standard Organisation). International Standard ISO 14044. Environmental management-Life Cycle AssessmentRequirements and Guidelines; ISO Copyright Office: Geneva, Switzerland, 2006.

16. European Communities. NACE Rev. 2 Statistical Classification of Economic Activities in the European Community; Office for Official Publications of the European Communities: Luxembourg, 2008. Available online: https://ec.europa.eu/eurostat/documents/38 59598/5902521/KS-RA-07-015-EN.PDF (accessed on 4 October 2021).

17. European Commission-Joint Research Centre-Institute for Environment and Sustainability. International Reference Life Cycle Data System (ILCD) Handbook_General Guide for Life Cycle Assessment_Detailed Guidance, 1st ed.; EUR 24708 EN; Publications Office of the European Union: Luxembourg, 2010. Available online: https:/ / eplca.jrc.ec.europa.eu/uploads/ILCD-HandbookGeneral-guide-for-LCA-DETAILED-GUIDANCE-12March2010-ISBN-fin-v1.0-EN.pdf (accessed on 27 August 2021).

18. European Commission-Joint Research Centre-Institute for Environment and Sustainability. Characterisation Factors of the ILCD Recommended Life Cycle Impact Assessment Methods. Database and Supporting Information, 1st ed.; EUR 25167; Publications Office of the European Union: Luxembourg, 2012. Available online: https:/ / eplca.jrc.ec.europa.eu/uploads/LCIA-characterizationfactors-of-the-ILCD.pdf (accessed on 27 August 2021).

19. Zhu, X.; Zhang, N.; Choi, Y. Regional Eco-efficiency and Environmental Risk Analysis in China Based on NUO-DEA Model. In Modeling Risk Management for Resources and Environment in China, Computational Risk Management, 1st ed.; Zhou, Y., Wu, D.D., Eds.; Springer: Berlin/Heidelberg, Germany, 2011; pp. 295-301.

20. Yannick, G.Z.S.; Zhao, H.; Thierry, B. Technical efficiency assessment using data envelopment analysis: An application to the banking sector of Côte d'Ivoire. Procedia-Soc. Behav. Sci. 2016, 235, 198-207. [CrossRef]

21. Didehkhani, H.; Lotfi, F.H.; Sadi-Nezhad, S. Practical benchmarking in DEA using artificial DMUs. J. Ind. Eng. Int. 2019, 15, 293-301. [CrossRef]

22. Banker, R.D.; Charnes, A.; Cooper, W.W. Some models for estimating technical and scale inefficiencies in Data Envelopment Analysis. Manag. Sci. 1984, 30, 1078-1092. [CrossRef]

23. Cooper, W.W. Data Envelopment Analysis: History, Models, and Interpretations. In Handbook on Data Envelopment Analysis, 2nd ed.; Cooper, W.W., Seiford, L.M., Zhu, J., Eds.; Springer: New York, NY, USA, 2011; pp. 1-39.

24. Sheng, Y.; Kim, Y. An Analysis on the Logistics Efficiency of Shanghai Port for Global Supply Chain. J. Distrib. Sci. 2021, 19, 29-39. 
25. Khan, B.M.; Pai, P.; Kachwala, T. Data Envelopment Analysis-Is BCC model better than CCR model? Case of Indian Life Insurance companies. NMIMS Manag. Rev. 2020, 38, 17-35.

26. Cooper, W.W.; Seiford, L.M.; Tone, K. Data Envelopment Analysis: A Comprehensive Text with Models, Applications, References and DEA-Solver Software, 2nd ed.; Springer: Berlin/Heidelberg, Germany, 2007. Available online: https://www.researchgate.net/ publication/32047675_Data_Envelopment_Analysis_A_Comprehensive_Text_with_Models_Applications_References_and_ DEA-Solver_Software (accessed on 5 September 2021).

27. Kuszewski, T.; Sielska, A. Efektywność sektora rolnego w województwach przed i po akcesji Polski do Unii Europejskiej [Polish agriculture sector performance by province before and after the country's accession to the European Union]. Gospod. Nar. 2012, 3, 19-42. [CrossRef]

28. Masternak-Janus, A.; Rybaczewska-Błażejowska, M. Comprehensive regional eco-efficiency analysis based on date envelopment analysis: The case study of Polish regions. J. Ind. Ecol. 2017, 21, 180-190. [CrossRef]

29. Guzik, B. Prosta metoda doboru zestawu nakładów w modelach DEA [Simple method for input selection in DEA models]. Przeglad Stat. 2009, 56, 74-90.

30. Pastor, J.; Ruiz, J.; Sirvent, I. A statistical test for nested radial dea models. Oper. Res. 2002, 50, 762-773. [CrossRef]

31. Jitthavech, J. Variable elimination in nested DEA models: A statistical approach. Int. J. Oper. Res. 2016, 27, 389-410. [CrossRef]

32. Central Statistical Office. Rocznik Statystyczny Przemystu [Statistical Yearbook of Industry-Poland]; CSO: Warsaw, Poland, 2020; pp. 367-469.

33. Ginger Santonja, G.; Karlis, P.; Stubdrup, K.R.; Brinkmann, T.; Roudier, S. Best Available Techniques (BAT) Reference Document for the Food, Drink and Milk Industries. Industrial Emissions Directive 2010/75/EU (Integrated Pollution Prevention and Control). Available online: https:/ / eippcb.jrc.ec.europa.eu/sites/default/ files/2020-01/JRC118627_FDM_Bref_2019_published. pdf (accessed on 8 September 2021).

34. Burchart-Korol, D. Środowiskowa ocena technologii hutnictwa żelaza i stali na podstawie LCA [Environment evaluation of iron and steel production technologies based on LCA]. Res. Rep. Min. Environ. 2010, 3, 5-13.

35. Polish Cement Association. Wptyw Branży Cementowej na Gospodarkę Polski [The Influence of the Cement Industry on the Polish Economy]; EY, SPC: Warsaw, Poland, 2020; pp. 68-81.

36. Wang, W.; Tian, G.; Chen, M.; Tao, F.; Zhang, C.; Al-Ahmari, A.; Li, Z.; Jiang, Z. Dual-objective program and improved artificial bee colony for the optimization of energy-conscious milling parameters subject to multiple constraints. J. Clean. Prod. 2020, 245, 118714. [CrossRef]

37. Polish Chamber of Chemical Industry. Przemyst Chemiczny w Polsce. Pozycja, Wyzwania, Perspektywy [Chemical Industry in Poland. Position, Challenges, Prospects]; PCCI: Warsaw, Poland, 2019; pp. 3-30. 